\title{
PREPARATION AND ADSORPTIVE PROPERTIES OF ACTIVATED CARBON FROM ACACIA LEUCOPHLOEA WOOD SAWDUST HYDROCHAR BY ZINC CHLORIDE ACTIVATION
}

\author{
SAMIYAPPAN NIRMALADEVI and NACHIMUTHU PALANISAMY \\ Centre for Environmental Research, Department of Chemistry, Kongu Engineering College, Perundurai, \\ Erode-638 060, Tamil Nadu, India \\ \Corresponding author: Samiyappan Nirmaladevi,devinks86@gmail.com
}

\begin{abstract}
Activated carbon was synthesized from Acacia leucophloea wood sawdust by a two stage chemical activation process. The first stage involved direct hydrolysis of the raw material to produce hydrochar. The second stage was the chemical activation of the hydrochar using $\mathrm{ZnCl}_{2}$. In the present study, chemical activation, focusing on the effects of the impregnation ratio, carbonization temperature and carbonization time, has been investigated and the optimum production conditions were found to be as follows: 6:1 impregnation ratio, $600{ }^{\circ} \mathrm{C}$ carbonization temperature and $1 \mathrm{~h}$ carbonization time. The precursor and the activated carbon produced under the optimum conditions were characterized by several analytical techniques, such as elemental and proximate analyses, FE-SEM, FT-IR, TGA and BET surface area analysis. The adsorption performance of the activated carbon prepared towards anionic dye Direct Blue 2B was evaluated. The Langmuir model showed a better fit to the isotherm data, while kinetic data were fitted by the pseudosecond order model.
\end{abstract}

Keywords: activated carbon, hydrochar, chemical activation, adsorption, wood sawdust

\section{INTRODUCTION}

Activated carbons are extensively used in many fields due to their high surface area, high porosity, variable functional groups, low ash content and high mechanical strength. ${ }^{1}$ Due to these advantages, the demand for activated carbon is constantly increasing. Activated carbons are commonly produced from carbonaceous materials that have high carbon but low inorganic content, however, their comparatively high costs limit their widespread use. ${ }^{2}$ In recent years, activated carbon has been produced from abundant, renewable and low-cost materials, which possess high carbon and low inorganic content. ${ }^{3-5}$ Sawdust is a biowaste of the wood industry, mainly composed of cellulose (40-50\%), hemicelluloses (20-40\%) and lignin (20-40\%). The accumulation of this residue causes environmental and health related issues. ${ }^{6}$ The use of sawdust from different wood species for removing heavy metals from aqueous solutions has been reported previously. ${ }^{7-9}$

Generally, activated carbons can be prepared through physical and chemical activation. Physical activation involves carbonization, followed by activation at high temperature by steam or carbon dioxide. In contrast, in chemical activation, raw materials are directly impregnated with activating agents and pyrolyzed. Recently, two-stage chemical activation processes have been reported in the literature..$^{10-12} \mathrm{~A}$ two-stage process comprises a pre-carbonization process, pyrolysis or hydrolysis, followed by chemical activation. Pyrolysis is carried out at high temperatures $\left(400-1200{ }^{\circ} \mathrm{C}\right)$ in an inert atmosphere under vacuum conditions or under oxygen limited conditions to produce biochar. ${ }^{13}$ In hydrolysis, the raw materials are dispersed in an autoclave containing a given solution of $\mathrm{H}_{2} \mathrm{O}$, $\mathrm{NaOH}$ or $\mathrm{H}_{3} \mathrm{PO}_{4},{ }^{14}$ and are heated up to $150-350$ ${ }^{\circ} \mathrm{C}$ for 2-24 h to produce hydrochar. ${ }^{15}$

Activated carbons prepared through the twostage chemical activation process have a larger surface area than those prepared using one-stage chemical activation. ${ }^{16}$ Activated carbon with a high BET surface area can be prepared from hydrochar based activated carbon. ${ }^{14}$ In the case of chemical activation, the activating agents have a strong influence on the characteristics of activated carbon.

Among the chemical activating agents, $\mathrm{ZnCl}_{2}$ is used to get a high specific surface area., ${ }^{2,17,18}$ 
Hence, $\mathrm{ZnCl}_{2}$ has been selected to be used as activating agent in the present study.

This study aims to utilize Acacia leucophloea wood sawdust (ALWSD) as a lignocellulosic precursor for the preparation of activated carbon by the two-stage chemical activation process. The effect of the impregnation ratio $\left(\mathrm{ZnCl}_{2} / \mathrm{HC}\right.$, w/w), carbonization temperature and time on the pore characteristics of the prepared activated carbons has been studied. The activated carbon prepared under the optimum conditions was denoted as ALHAC. In addition, the surface morphology of the prepared activated carbon (ALHAC) and its adsorption ability towards Direct Blue 2B, in terms of kinetics, isotherms and thermodynamics, were studied.

\section{EXPERIMENTAL \\ Materials}

The precursor Acacia leucophloea wood sawdust (ALWSD) was collected from local saw mills. It was washed with water to remove impurities and dried in sunlight. $\mathrm{ZnCl}_{2}$ with $99.9 \%$ purity was used as chemical activating agent to produce activated carbon. Direct Blue 2B was purchased from local dye suppliers and used as received.

Approximately $13 \mathrm{~g}$ of the precursor was mixed with $50 \mathrm{~mL}$ of distilled water in a $100 \mathrm{~mL}$ Teflon-lined autoclave at $210{ }^{\circ} \mathrm{C}$ for $6 \mathrm{~h}$ to produce hydrochar. Activated carbon was synthesized by chemical activation of the hydrochar with $\mathrm{ZnCl}_{2}$. The optimum conditions for the activated carbon preparation from the hydrochar were determined by studying the effect of the impregnation ratio $(1: 1,2: 1,4: 1,6: 1,8: 1$ $\mathrm{ZnCl}_{2} / \mathrm{HC}$, w/w), carbonization temperature $(500,600$, 700 and $\left.800{ }^{\circ} \mathrm{C}\right)$ and carbonization time $(0.5,1.0,2 \mathrm{~h})$. The results are presented in Table 1. All these experiments were performed in a muffle furnace in a lid-enclosed crucible. The activated carbon produced under the optimum conditions was denoted ALHAC. Finally, ALHAC was washed with distilled water until the $\mathrm{pH}$ of the filtrates reached a constant value. The sample was then dried and stored for further use.

\section{Characterization}

ALWSD was characterized by

thermogravimetry/differential thermogravimetry (TG/DTA) analysis, proximate and elemental analyses, field emission scanning electron microscopy (FESEM), FT-IR analysis and BET method, while ALHAC was characterized by proximate and elemental analyses, FT-IR and FESEM, as well as in terms of pore structure. The thermal behavior of the raw material was measured with a thermogravimetric analyzer (Perkin Elmer, Diamond TG/DTA). About 10 $\mathrm{mg}$ of sample was heated from $25^{\circ} \mathrm{C}$ to $800{ }^{\circ} \mathrm{C}$ at a rate of $10^{\circ} \mathrm{C} / \mathrm{min}$ under gas atmosphere. The percent weight loss versus temperature and derivative weight loss versus temperature were plotted for TG and DTA, respectively. The elemental analysis $(\mathrm{C}, \mathrm{H}, \mathrm{N}$ and $\mathrm{S})$ was determined with an elemental analyzer (Elementar Vario EL III), while proximate analysis was done according to ASTM test standards. Surface morphology was identified by a TESCAN FESEM. Surface area and pore characteristics were measured by $\mathrm{N}_{2}$ adsorption-desorption isotherms at $77 \mathrm{~K}$ (Autosorb1, Quanta chrome). The surface area $\left(\mathrm{S}_{\mathrm{BET}}\right)$ of the raw material and prepared carbons was measured by the BET method. Micropore surface area $\left(S_{\mu}\right)$ was estimated by the t-plot method. The total pore volume $\left(\mathrm{V}_{\mathrm{T}}\right)$ was measured to be the volume of $\mathrm{N}_{2}$ at high relative pressure $\left(\mathrm{p} / \mathrm{p}_{0}=0.99\right)$. Likewise, the micropore volume $\left(\mathrm{V}_{\mu}\right)$ was obtained using the DR method, and mesopore volume $\left(\mathrm{V}_{\mathrm{m}}\right)$ was calculated by subtracting $\mathrm{V}_{\mu}$ from $\mathrm{V}_{\mathrm{T}}$, while $\mathrm{V}_{\mu}(\%)$ and $\mathrm{V}_{\mathrm{m}}(\%)$ are based on $\mathrm{V}_{\mathrm{T}}$.

Table 1 Experimental conditions for the production of activated carbons and their pore characteristics

\section{RESULTS AND DISCUSSION \\ Selection of optimum conditions for the production of activated carbon}

To determine the optimum conditions for the preparation of activated carbon (AC), the effects of carbonization temperature, carbonization time and impregnation ratio on the pore characteristics were found from the nitrogen adsorptiondesorption isotherms and pore size distribution (inset graph) shown in Figure 1. The results obtained are discussed below.

\section{Effect of impregnation ratio}

The effects of impregnation ratio $\left(\mathrm{ZnCl}_{2} / \mathrm{HC}\right.$, $\mathrm{w} / \mathrm{w}$ ) on the $\mathrm{S}_{\mathrm{BET}}$ and pore characteristics of the ACs produced at a carbonization temperature of $500{ }^{\circ} \mathrm{C}$ and carbonization time of $1 \mathrm{~h}$ are shown in Table 1. As seen from the table, when the impregnation ratio is increased from 1 to 6 , the $\mathrm{S}_{\mathrm{BET}}$ of the activated carbons increased from 102 to $649 \mathrm{~m}^{2} / \mathrm{g}$, while $\mathrm{V}_{\mathrm{T}}, \mathrm{V}_{\text {mes }}(\%)$ and $\mathrm{D}_{\mathrm{p}}$ values increased from 0.056 to $0.382 \mathrm{~cm}^{3} / \mathrm{g}$, from 4 to $25 \%$ and from 2.21 to $2.35 \mathrm{~nm}$, respectively. The values have been found to decrease beyond the $6: 1$ ratio. Similar results have been obtained from chemical activation of tomato processing solid waste with $\mathrm{ZnCl}_{2}{ }^{18}$ The results reveal that the $\mathrm{ZnCl}_{2}$ impregnation ratio strongly influences porosity. At a low impregnation ratio, $\mathrm{ZnCl}_{2}$ inhibits the tar formation and it leads to micropores. Further, at a high impregnation ratio, 
the release of volatiles leads to the formation of mesopores. $^{20}$ Hence, the ratio of $6: 1$ was established as the optimum impregnation ratio.

\section{Effect of carbonization temperature}

Activated carbon was produced at various temperatures for the carbonization time of $1 \mathrm{~h}$, with the impregnation ratio of $6: 1$. As seen from Table 1, when the temperature is increased from 500 to $700{ }^{\circ} \mathrm{C}$, the $\mathrm{S}_{\mathrm{BET}}$ and the pore characteristic values are increased from 762 to $1380 \mathrm{~m}^{2} / \mathrm{g}$, from 0.396 to $0.727 \mathrm{~cm}^{3} / \mathrm{g}$, from 17 to $19 \%$ and from 2.11 to $2.27 \mathrm{~nm}$, respectively, while after $700{ }^{\circ} \mathrm{C}$, these values start decreasing. This is due to the sintering effect occurring at high temperature, which results in narrowing and closing up some of the pores. ${ }^{21,22} \mathrm{~A}$ similar trend has been reported by the chemical activation of lignin using $\mathrm{ZnCl}_{2}{ }^{19}$ Hence, $600{ }^{\circ} \mathrm{C}$ has been chosen as the optimum temperature for the carbonization process and further experiments were conducted at this temperature.

\section{Effect of carbonization time}

Activated carbon was produced at various carbonization times of 0.5 to $2 \mathrm{~h}$, at the impregnation ratio of $6: 1$ and carbonization temperature of $600{ }^{\circ} \mathrm{C}$. As seen from Table 1, when the time is increased from 0.5 to $1 \mathrm{~h}$, the $\mathrm{S}_{\mathrm{BET}}$ and the pore characteristic values increase from 1308 to $1380 \mathrm{~m}^{2} / \mathrm{g}$, from 0.678 to 0.727 $\mathrm{cm}^{3} / \mathrm{g}$, from 13 to $19 \%$ and from 1.93 to $2.27 \mathrm{~nm}$, respectively, while a prolonged carbonization time from 1 to $2 \mathrm{~h}$ leads to a decrease of these values. This may be caused by pore sealing, resulting from the prolonged time for sintering. ${ }^{23}$ Therefore, the carbonization time of $1 \mathrm{~h}$ was selected for further experiments.

\section{Process optimization}

As can be seen from Table 1, the optimal activated carbon has the highest $\mathrm{S}_{\mathrm{BET}}\left(1380 \mathrm{~m}^{2} / \mathrm{g}\right)$, $\mathrm{V}_{\mathrm{T}}\left(0.727 \mathrm{~cm}^{3} / \mathrm{g}\right), \mathrm{V}_{\text {mes }}(\%)(19 \%)$ and $\mathrm{D}_{\mathrm{P}}(2.27$ $\mathrm{nm})$. This is the activated carbon achieved using a 6:1 impregnation ratio $\left(\mathrm{ZnCl}_{2} / \mathrm{HC}\right), 600{ }^{\circ} \mathrm{C}$ carbonization temperature and $1 \mathrm{~h}$ carbonization time. The activated carbon produced under the optimum conditions was labeled ALHAC. Further, its adsorptive performance was tested by using DB2B from the aqueous solution.
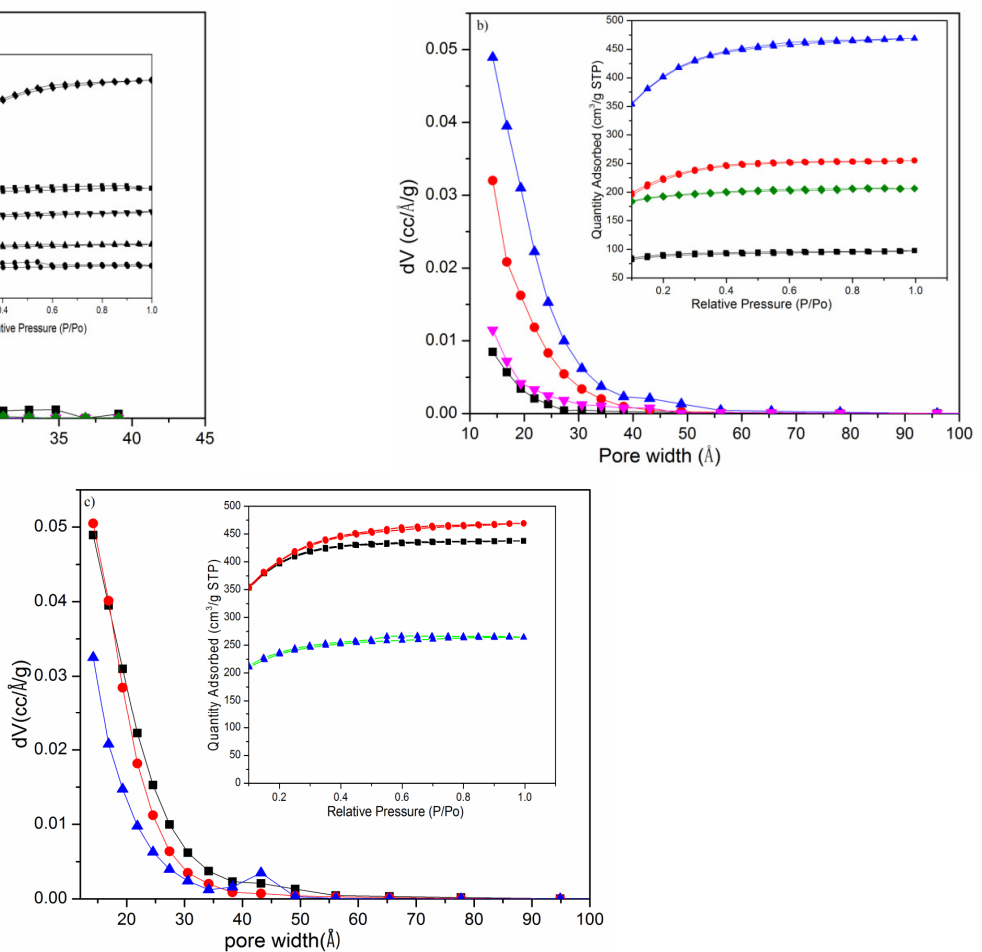

Figure 1: Nitrogen adsorption-desorption isotherms and pore size distribution (inset graph) for ACs prepared from ALWSD at different a) impregnation ratios, b) carbonization temperatures and (c) carbonization times 
SAMIYAPPAN NIRMALADEVI and NACHIMUTHU PALANISAMY

Table 2

Experimental conditions for the production of activated carbons and their pore characteristics

\begin{tabular}{|c|c|c|c|c|c|c|c|c|c|}
\hline IR (w/w) & $\mathrm{CT}\left({ }^{\circ} \mathrm{C}\right)$ & $\mathrm{Ct}(\mathrm{h})$ & $\mathrm{S}_{\mathrm{BET}\left(\mathrm{m}^{2} / \mathrm{g}\right)}$ & $V_{\mathrm{T}(\mathrm{cm} / \mathrm{g})}^{3}$ & $\mathrm{~V}_{\text {mic }(\mathrm{cm} / \mathrm{g})}$ & $\mathrm{V}_{\text {mic }(\%)}$ & $\mathrm{V}_{\mathrm{mes}(\mathrm{cm} / \mathrm{g})}$ & $\mathrm{V}_{\text {mes }(\%)}$ & $\mathrm{D}_{\mathrm{p}(\mathrm{nm})}$ \\
\hline \multicolumn{10}{|c|}{ Effect of impregnation ratio } \\
\hline $1: 1$ & 500 & 1 & 102 & 0.056 & 0.054 & 96 & 0.002 & 4 & 2.21 \\
\hline $2: 1$ & 500 & 1 & 171 & 0.094 & 0.085 & 90 & 0.009 & 10 & 2.19 \\
\hline 4:1 & 500 & 1 & 450 & 0.198 & 0.185 & 93 & 0.013 & 7 & 1.76 \\
\hline $6: 1$ & 500 & 1 & 649 & 0.382 & 0.286 & 75 & 0.096 & 25 & 2.35 \\
\hline $8: 1$ & 500 & 1 & 265 & 0.152 & 0.133 & 88 & 0.019 & 13 & 2.29 \\
\hline \multicolumn{10}{|c|}{ Effect of carbonization temperature } \\
\hline $6: 1$ & 600 & 1 & 762 & 0.396 & 0.329 & 84 & 0.067 & 17 & 2.11 \\
\hline $6: 1$ & 700 & 1 & 1380 & 0.727 & 0.589 & 81 & 0.138 & 19 & 2.27 \\
\hline $6: 1$ & 800 & 1 & 711 & 0.320 & 0.291 & 90 & 0.029 & 9 & 1.79 \\
\hline \multicolumn{10}{|c|}{ Effect of carbonization time } \\
\hline $6: 1$ & 700 & 0.5 & 1308 & 0.678 & 0.588 & 86 & 0.09 & 13 & 1.93 \\
\hline $6: 1$ & 700 & 2 & 825 & 0.409 & 0.347 & 85 & 0.062 & 15 & 1.98 \\
\hline
\end{tabular}

IR: impregnation ratio; CT: carbonization temperature; $\mathrm{Ct}$ : carbonization time 
Table 2

Proximate and ultimate analysis results for ALWSD and ALHAC

\begin{tabular}{|c|c|c|}
\hline Analysis & ALWSD (\%) & ALHAC $(\%)$ \\
\hline \multicolumn{3}{|l|}{ Proximate } \\
\hline Moisture & 14.95 & 7.14 \\
\hline Volatile matter & 60.06 & 79.49 \\
\hline Ash & 5.88 & 0.98 \\
\hline Fixed carbon ${ }^{a}$ & 19.11 & 12.39 \\
\hline \multicolumn{3}{|l|}{ Ultimate } \\
\hline Carbon & 41.78 & 54.08 \\
\hline Hydrogen & 6.17 & 3.67 \\
\hline Nitrogen & 0.81 & 1.69 \\
\hline Sulphur & 0.11 & 0.07 \\
\hline Oxygen $^{a}$ & 51.13 & 40.49 \\
\hline
\end{tabular}

${ }^{a}$ by difference

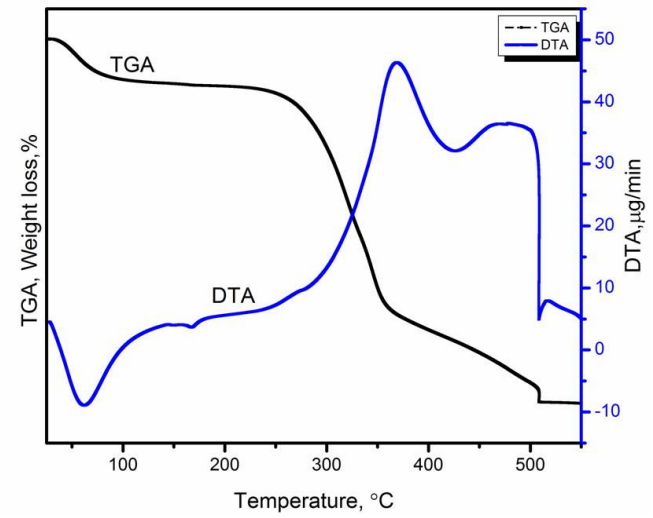

Figure 2: TGA and DTA curves of ALWSD

Proximate and ultimate analysis results for ALWSD and ALHAC

The proximate and ultimate analyses of ALWSD and ALHAC are shown in Table 2. As can be seen from the table, ALWSD can serve as a good starting material for the preparation of porous activated carbon due to its relatively low ash content (5.88\%), high carbon content $(41.78 \%)$ and high volatile content $(60.06 \%) .{ }^{1}$ It can also be seen from Table 2 that the contents of carbon and volatile matter get increased in ALHAC, whereas the contents of hydrogen, sulphur and oxygen get decreased. This may be due to the removal of volatile matter containing $\mathrm{H}, \mathrm{O}$ and $\mathrm{S}$ during carbonization, which may yield carbon-rich species. This is explained by the fact that $\mathrm{ZnCl}_{2}$ would selectively stripe $\mathrm{H}$ and $\mathrm{O}$ away from ALWSD as $\mathrm{H}_{2} \mathrm{O}$ and $\mathrm{H}_{2}$ rather than $\mathrm{CO}$ or $\mathrm{CO}_{2}{ }^{18,24}$ Moreover, ALHAC has also low ash content $(0.98 \%)$, which may lead to better removal of organic substances from an aqueous solution due to the hydrophobicity of the material. ${ }^{25}$

\section{Thermal analysis of the raw material}

The thermal characteristics of ALWSD were also determined using TGA-DTA, and the thermogravimetric curves are shown in Figure 2. As can be seen from the figure, the decomposition of ALWSD occurs in four stages. The first stage, which occurs at temperatures ranging from room temperature to $150{ }^{\circ} \mathrm{C}$, involves the loss of the moisture content present in the precursor, with approximately $12.3 \%$ weight loss. In the second stage, the weight loss of $29.8 \%$ occurs at $150-310$ ${ }^{\circ} \mathrm{C}$. This is caused by the release of volatile matters, resulting from the decomposition of hemicelluloses. The third stage, with the maximum rate of weight loss of $38.1 \%$, occurs at 310-480 ${ }^{\circ} \mathrm{C}$ because of the decomposition of cellulose and lignin. ${ }^{18}$ No significant weight loss was observed above $480{ }^{\circ} \mathrm{C}$ and therefore, $500{ }^{\circ} \mathrm{C}$ 
can be fixed as the lowest carbonization temperature for activated carbon production from ALWSD. In the DTA spectrum, the peak at $62{ }^{\circ} \mathrm{C}$ corresponds to the removal of water.

\section{SEM analysis}

FESEM images of ALWSD and ALHAC have been shown in Figure 3. Significant differences between the surface morphology of ALWSD and that of ALHAC can be observed in the micrographs. The surface of ALWSD is relatively smooth, while the prepared activated carbon has irregular surface morphology. The pores are formed due to the reaction between $\mathrm{ZnCl}_{2}$ and carbon. It is evident from the micrograph that ALHAC can be used as a better adsorbent in the removal of organic pollutants from aqueous solutions. This is supported by the pore characteristics of ALHAC, as presented in Table 1 .

\section{FT-IR analysis}

To identify the functional groups present on the surface of ALWSD and ALHAC, FT-IR

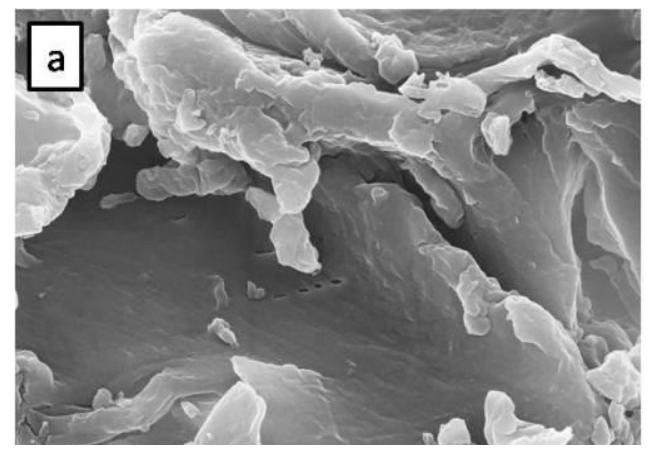

spectra were recorded and shown in Figure 4. The spectra of ALWSD indicate the complex nature of the material. In the spectra of ALWSD, the bands at 3332 and $3524 \mathrm{~cm}^{-1}$ are attributed to the $-\mathrm{OH}$ stretching vibrations of cellulose, pectin, absorbed water, hemicelluloses and lignin. ${ }^{26}$ The peak at $2899 \mathrm{~cm}^{-1}$ is ascribed to the aliphatic C-H stretching vibration. The band at 1736 and 1638 $\mathrm{cm}^{-1}$ indicates the $\mathrm{C}=\mathrm{O}$ group from the carboxyl group. The signals at $1250-1000 \mathrm{~cm}^{-1}$ were attributed to the $\mathrm{C}-\mathrm{O}$ stretching vibration. After activation, in the FT-IR spectra of ALHAC, some of the peaks have disappeared or weakened. The band corresponding to $\mathrm{O}-\mathrm{H}$ stretching vibrations shifted to a higher wavenumber $-3449 \mathrm{~cm}^{-1}$. The band at $2880 \mathrm{~cm}^{-1}$ is due to the stretching vibration of the methyl group. The band at 1631 $\mathrm{cm}^{-1}$ corresponds to carbonyl from the carboxyl group and the peak at $1266 \mathrm{~cm}^{-1}$ indicates the presence of $\mathrm{C}=\mathrm{O}$ stretching vibration. The lower number of absorption bands in the spectrum of ALHAC, compared to that of ALWSD, may be explained by the vaporization of organic matter at elevated temperatures. ${ }^{18}$

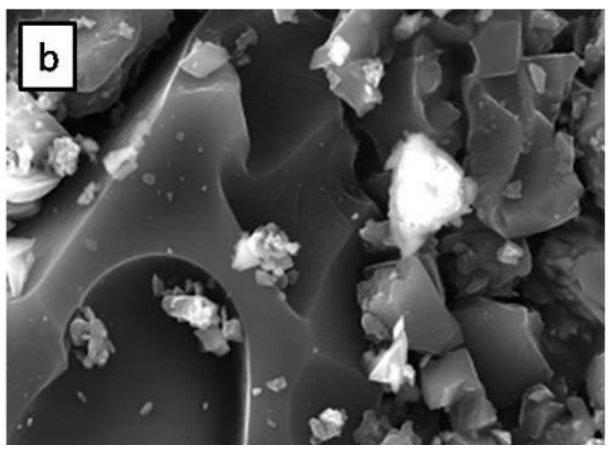

Figure 3: FESEM micrographs of a) ALWSD and b) ALHAC

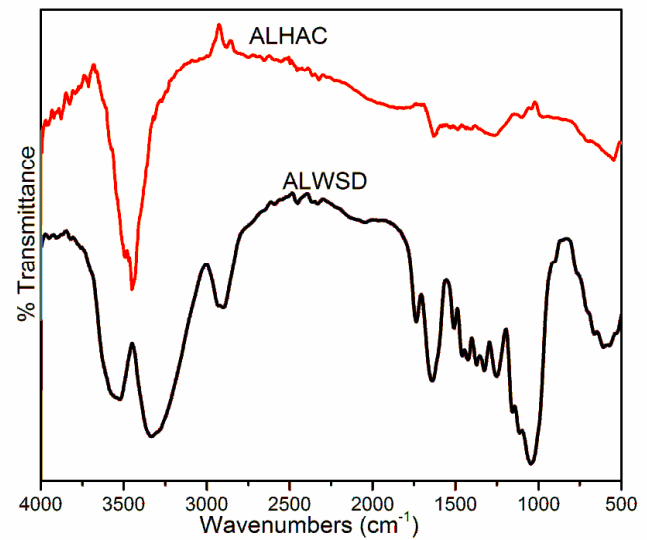

Figure 4: FT-IR spectra of ALWSD and ALHAC 


\section{Adsorption experiments}

The adsorption of DB2B onto ALHAC was determined by batch mode adsorption experiments. The effect of different parameters, such as contact time, solution $\mathrm{pH}(2-11)$ and initial concentration, was investigated. Experiments were performed in a series of 250 $\mathrm{mL}$ Erlenmeyer flasks, containing $50 \mathrm{~mL}$ of DB2B solution. The flasks were placed in an orbital shaker (REMI, RIS-24BL) for agitation at a fixed shaking speed of $170 \mathrm{rpm}$ for the specified time. The effect of contact time and initial concentration was studied at $30{ }^{\circ} \mathrm{C}$, natural $\mathrm{pH}$ and initial dye concentrations of $20-100 \mathrm{mg} / \mathrm{L}$. The influence of solution $\mathrm{pH}$ on the adsorption was determined at $\mathrm{pH} 2-11$ for the dye concentration of $50 \mathrm{mg} / \mathrm{L}$, by adding $0.1 \mathrm{M} \mathrm{HCl}$ or $\mathrm{NaOH}$. The final concentration of DB2B was measured by a UV-Visible absorption spectrophotometer (Elico: DR3900) at a wavelength of $\lambda_{\max }=586 \mathrm{~nm}$.

The quantity of the dye adsorbed $\mathrm{q}_{\mathrm{e}}(\mathrm{mg} / \mathrm{g})$ and dye removal (\%) were determined as follows:

$\mathrm{q}_{\mathrm{e}}=\frac{\left(c_{\mathrm{i}}-c_{\mathrm{z}}\right) v}{m}$

where $\mathrm{V}$ is the solution volume $(\mathrm{L}), \mathrm{m}$ is the mass of adsorbent $(\mathrm{g})$ and $\mathrm{C}_{\mathrm{i}}$ and $\mathrm{C}_{\mathrm{e}}$ are the initial and equilibrium concentrations of DB2B $\left(\mathrm{mgL}^{-1}\right)$, respectively;

$\%$ of dye removal $=\left(\frac{C_{i}-C_{e}}{c_{\mathrm{I}}}\right) \times 100$

\section{Adsorption isotherms and kinetics}

A set of batch mode experiments were carried out to determine the adsorption isotherms and kinetics of the ALHAC-DB2B system. Isotherm studies were also conducted by adding $50 \mathrm{~mL}$ of the dye solution with different dye concentrations of $10-100 \mathrm{mg} / \mathrm{L}$ into $250 \mathrm{~mL}$ Erlenmeyer flasks. These flasks were shaken by adding equal amounts $(50 \mathrm{mg}$ ) of ALHAC to each flask, at a shaking speed of $170 \mathrm{rpm}$ at 27,37 and $47{ }^{\circ} \mathrm{C}$, at natural $\mathrm{pH}$ of the dye solution for $3 \mathrm{~h}$. For the kinetic studies, $50 \mathrm{~mL}$ of the dye solution, with different dye concentrations of $20-100 \mathrm{mg} / \mathrm{L}$ and an ALHAC dose of $50 \mathrm{mg}$, was placed into flasks, at natural $\mathrm{pH}$ and at a temperature of $30^{\circ} \mathrm{C}$. The flasks were subjected to shaking. Similarly, equal amounts of aliquots were withdrawn at specified time intervals and the adsorbed amount of dye was determined each time.

\section{Adsorption performance Effect of initial concentration}

Figure 5 shows the adsorption performance of ALHAC as the percentage of DB2B removal versus contact time at initial dye concentrations from 20 to $100 \mathrm{mg} / \mathrm{L}$. It can be seen that the performance increases over time until equilibrium is attained. For low dye concentrations, a rapid increase in adsorption performance is observed within a contact time of 40 minutes, after which, it becomes moderate. Thereafter, no appreciable change in performance is observed. Initially, a lot of active sites are available for adsorption. During the process, a limited number of empty sites are still available for adsorption and these sites are occupied slowly because of the increase in the competition among the dye molecules for adsorption. In the present study, for the ALHACDB2B system, the equilibrium time has been attained at 140 minutes for all the studied concentrations. Further, it can be observed from Figure 5 that, for higher concentrations, the performance of ALHAC decreases. This may be a sign of dye aggregation, as dye ions have the tendency to aggregate in aqueous solutions at higher initial concentrations. ${ }^{19}$

\section{Effect of solution $\mathrm{pH}$}

The adsorption performance of ALHAC in terms of DB2B removal versus $\mathrm{pH}(2-12)$ is shown in Figure 6. The $\mathrm{pH}_{\mathrm{PZC}}$ is the $\mathrm{pH}$ where the net surface charge of the adsorbent corresponds to zero, and it could be used to describe the electrostatic relation between the adsorbent and the adsorbate. The $\mathrm{pH}_{\mathrm{pzc}}$ of ALHAC has been determined by the drift method and the value is 7.6. The surface of ALHAC is positive at $\mathrm{pH} 7.6$ and below. Figure 6 shows that when the $\mathrm{pH}$ is increased from 2 to 11 , the adsorption performance decreases from $91 \%$ to $60 \%$. This implies that acidic $\mathrm{pH}$ could provide a favorable site to enhance the electrostatic relation between the positively charged adsorbent and the anionic dye, while basic $\mathrm{pH}$ decreases the electrostatic interaction. However, there is a slight increase in

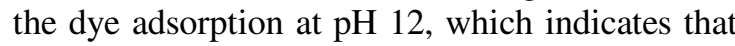
DB2B adsorption on ALHAC follows not only the electrostatic mode of adsorption, but is also controlled by some other mode of adsorption. 


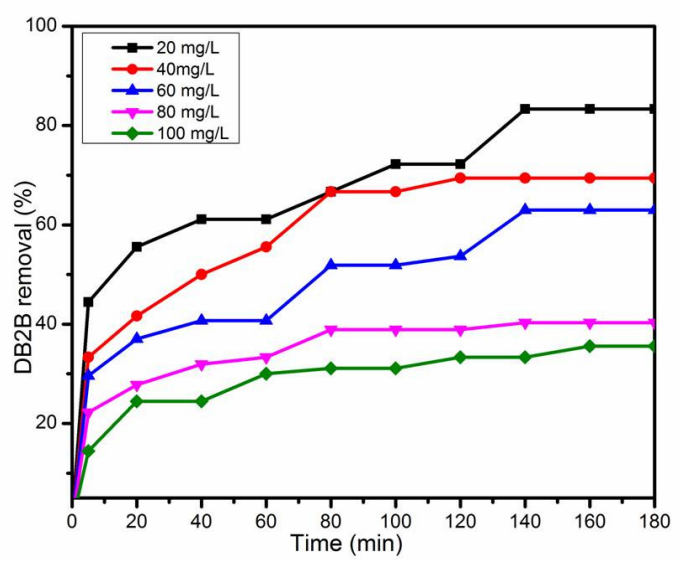

Figure 5: Performance of ALHAC towards DB2B removal at various concentrations $(\mathrm{w}=50 \mathrm{mg}, \mathrm{V}=50$ $\mathrm{mL}$, Temperature $=30^{\circ} \mathrm{C}$ )

\section{Adsorption isotherm}

Adsorption isotherms are useful to describe the relationship between the adsorbent and the adsorbate at constant temperature and design adsorption systems. ${ }^{27}$ In the current study, linear forms of Langmuir isotherm, ${ }^{28}$ Freundlich isotherm $^{29}$ and Temkin isotherm ${ }^{30}$ have been applied to study the adsorption isotherms, as follows:

Langmuir isotherm $\frac{c_{E}}{q_{e}}=\left(\frac{1}{Q_{\max }^{g}}\right) C_{t}+\frac{1}{Q_{\max }^{Q} K_{L}}$ (3)

where $\mathrm{Q}_{\text {max }}^{0}(\mathrm{mg} / \mathrm{g})$ is the maximum saturated monolayer adsorption capacity of an adsorbent and $\mathrm{K}_{\mathrm{L}}(\mathrm{L} / \mathrm{mg})$ is the Langmuir constant;

Freundlich isotherm $\log \mathrm{q}_{\mathrm{e}}=\mathrm{n} \log \mathrm{C}_{\mathrm{e}}+\log \mathrm{K}_{\mathrm{F}}$ (4) where $K_{F}(\mathrm{mg} / \mathrm{g})$ is the Freundlich's constant and $\mathrm{n}$ is the measure of the effectiveness of the adsorption process;

Temkin isotherm $\mathrm{q}_{\mathrm{e}}=\mathrm{B} \ln \mathrm{C}_{\mathrm{e}}+\mathrm{B} \ln \mathrm{A}$

where $\mathrm{B}=\mathrm{RT} / \mathrm{b}, \mathrm{R}$ is the universal gas constant $(8.314 \mathrm{~J} / \mathrm{mol} / \mathrm{K})$ and $\mathrm{T}$ is the absolute temperature in $\mathrm{K}, \mathrm{B}$ is related to the enthalpy of adsorption, $\mathrm{b}$ is the Temkin constant related to the heat of sorption $(\mathrm{J} / \mathrm{mol})$ and $\mathrm{A}$ is the equilibrium binding constant $(\mathrm{L} / \mathrm{g})$.

Experimental equilibrium data for the adsorption of ALHAC onto DB2B were fitted to the Langmuir, Freundlich and Temkin isotherms in Equations (3)-(5). The isotherm parameters were obtained by taking the slope and the intercept of the plots $\mathrm{C}_{\mathrm{e}} / \mathrm{q}_{\mathrm{e}} v s . \mathrm{C}_{\mathrm{e}}, \log \mathrm{q}_{\mathrm{e}} v s . \log \mathrm{C}_{\mathrm{e}}$ and $\mathrm{q}_{\mathrm{e}} v s . \ln \mathrm{C}_{\mathrm{e}}$ (figure not shown). The isotherm parameters and the $\mathrm{R}^{2}$ values calculated are summarized in Table 3. As seen from the table, the $\mathrm{R}^{2}$ value determined for all the three models

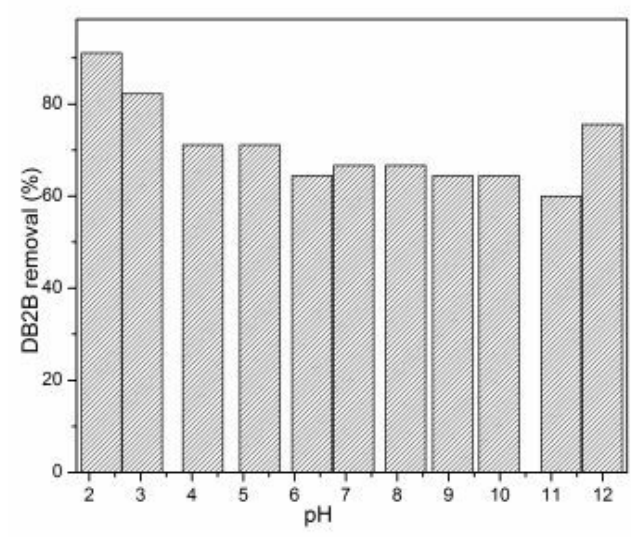

Figure 6: $\mathrm{pH}$ versus percentage of removal of ALHAC-DB2B system

indicates that the Langmuir model has better fitting to the data for all the studied concentrations. This observation implies monolayer adsorption of the dye molecules onto the surface of ALHAC. The maximum adsorption capacity of DB2B on ALHAC is of $37 \mathrm{mg} / \mathrm{g}$ at 30 ${ }^{\circ} \mathrm{C}$. In addition, the value of $\mathrm{n}$ in the Freundlich isotherm is found to be between 0 and 1 , indicating a favorable adsorption process. ${ }^{24}$ Hence, ALWSD can be used as a precursor for producing adsorbents with good affinity for DB2B dyes.

\section{Adsorption kinetics}

The experimental data regarding the dye uptake versus contact time and their analysis are useful to obtain the required equilibration time and to investigate the mechanism of the adsorption process. ${ }^{31}$ In the present study, two kinetic models, namely, a pseudo-first order ${ }^{32}$ and a pseudo-second order model,${ }^{33}$ have been applied to describe the adsorption kinetics. The linear forms of these equations are as follows:

Pseudo-first order $\log \left(\mathrm{q}_{\mathrm{e}}-\mathrm{q}_{\mathrm{t}}\right)=-\frac{k_{\mathrm{h}}}{2.303} \mathrm{t}+$

$\log \left(\mathrm{q}_{\mathrm{e}}\right)$

Pseudo-second order $\frac{\frac{t}{2}}{q_{t}}=\left(\frac{1}{q_{q}}\right) t+\frac{1}{q_{e}^{2} k_{2}}$

where $\mathrm{q}_{\mathrm{e}}(\mathrm{mg} / \mathrm{g})$ and $\mathrm{q}_{\mathrm{t}}(\mathrm{mg} / \mathrm{g})$ are the adsorbed amount of dye at equilibrium and at time $\mathrm{t}(\mathrm{min})$, respectively, while $\mathrm{k}_{1}(1 / \mathrm{min})$ and $\mathrm{k}_{2}(\mathrm{~g} / \mathrm{mg} / \mathrm{min})$ are the rate constants for both the models.

To evaluate the adsorption dynamics, the pseudo-first order and the pseudo-second order models have been applied to the analysis of the experimental kinetic data at various DB2B 
concentrations at $30{ }^{\circ} \mathrm{C}$. The results are presented in Table 3. The low $\mathrm{R}^{2}$ value for the linear plot of $\log \left(\mathrm{q}_{\mathrm{e}}-\mathrm{q}_{\mathrm{t}}\right) v s$. $\mathrm{t}$ shows poor data fitting by the pseudo-first order model. Nevertheless, the linear plot of $\mathrm{t} / \mathrm{q}_{\mathrm{t}} v s$. $\mathrm{t}$ for the pseudo-second order model displays a high $\mathrm{R}^{2}$ value. Hence, the kinetic data of the DB2B-ALHAC system are best fitted by the pseudo-second order model and chemisorption may be the rate-determining step.

\section{Thermodynamic studies}

The thermodynamic adsorption parameters, such as standard free energy change $\Delta \mathrm{G}^{0}$, entropy change $\Delta \mathrm{S}^{0}$ and enthalpy change $\Delta \mathrm{H}^{0}$, can be used to predict the adsorption mechanism. The parameters of $\Delta \mathrm{G}^{0}, \Delta \mathrm{S}^{0}$ and $\Delta \mathrm{H}^{0}$ can be calculated as follows: ${ }^{34}$

$$
\begin{array}{ll}
\mathrm{K}_{\mathrm{C}} & =932.74 * 55.5 * 1000 * \mathrm{~K}_{\mathrm{L}} \\
\Delta \mathrm{G}^{0} & =-\mathrm{RT} \ln \left(932.74 * 55.5 * 1000 * \mathrm{~K}_{\mathrm{L}}\right)
\end{array}
$$

$\ln \left(932.74 * 55.5 * 1000 * \mathrm{~K}_{\mathrm{L}}\right)=\frac{-\Delta H^{\circ}}{R} \times \frac{1}{T}+\frac{\Delta 5^{\circ}}{R}(10)$ where 55.5 is the number of moles of pure water per liter, 932.74 is the molecular weight of the adsorbate and $\mathrm{K}_{\mathrm{C}}$ is the dimensionless equilibrium constant. The value of $\Delta \mathrm{G}^{0}$ can be calculated directly from Equation (9), while $\Delta \mathrm{H}^{0}$ and $\Delta \mathrm{S}^{0}$ are determined from the slope and the intercept of the plot $\ln \mathrm{K}_{\mathrm{C}}$ against $1 / \mathrm{T}$. The calculated thermodynamic parameters are shown in Table 5. Furthermore, the negative value of $\Delta \mathrm{G}^{0}$ for all the studied temperatures confirms that the adsorption of DB2B onto ALHAC is a favorable and spontaneous process. The negative $\Delta \mathrm{H}^{0}$ value reveals the exothermic nature of the adsorption process. In addition, the negative value of $\Delta S^{0}$ indicates that the adsorption process occurs by decreased randomness. ${ }^{35}$

Table 3

Isotherm parameters of DB2B adsorption on ALHAC

\begin{tabular}{lcc}
\hline Isotherms & Parameters & Values at $27{ }^{\circ} \mathrm{C}$ \\
\hline \multirow{3}{*}{ Langmuir } & $\mathrm{Q}^{0} \max (\mathrm{mg} / \mathrm{g})$ & 37 \\
& $\mathrm{~K}_{\mathrm{L}}(\mathrm{L} / \mathrm{mg})$ & 0.53 \\
& $\mathrm{R}^{2}$ & 0.97 \\
\hline \multirow{3}{*}{ Freundlich } & $\mathrm{K}_{\mathrm{F}}(\mathrm{mg} / \mathrm{g})$ & 11.55 \\
& $\mathrm{n}$ & 0.33 \\
& $\mathrm{R}^{2}$ & 0.72 \\
\multirow{3}{*}{ Temkin } & $\mathrm{A}(\mathrm{L} / \mathrm{g})$ & 0.49 \\
& $\mathrm{~B}$ & 7.07 \\
& $\mathrm{R}^{2}$ & 0.63 \\
\hline
\end{tabular}

Table 4

Pseudo-first order and pseudo-second order kinetic parameters for DB2B adsorption on ALHAC at $30{ }^{\circ} \mathrm{C}$

\begin{tabular}{cccccccc}
\hline \multirow{2}{*}{$\mathrm{C}_{0}(\mathrm{mg} / \mathrm{L})$} & $\mathrm{q}_{\exp }$ & \multicolumn{3}{c}{ Pseudo-first order } & \multicolumn{3}{c}{ Pseudo-second order } \\
\cline { 3 - 8 } & $(\mathrm{mg} / \mathrm{L})$ & $\mathrm{q}_{\mathrm{cal}}(\mathrm{mg} / \mathrm{L})$ & $\mathrm{K}_{1}$ & $\mathrm{R}^{2}$ & $\mathrm{q}_{\text {cal }}(\mathrm{mg} / \mathrm{L})$ & $\mathrm{K}_{2}$ & $\mathrm{R}^{2}$ \\
\hline 20 & 16.67 & 7.52 & 0.0107 & 0.94 & 17.77 & 0.0033 & 0.98 \\
40 & 27.78 & 20.66 & 0.0299 & 0.88 & 30.27 & 0.0023 & 0.99 \\
60 & 37.78 & 20.93 & 0.0114 & 0.91 & 41.58 & 0.0010 & 0.96 \\
80 & 32.22 & 16.76 & 0.0255 & 0.88 & 34.09 & 0.0023 & 0.99 \\
100 & 35.56 & 18.45 & 0.0162 & 0.93 & 37.68 & 0.0018 & 0.99 \\
\hline
\end{tabular}

Table 5

Adsorption thermodynamic parameters for DB2B onto ALHAC

\begin{tabular}{ccccc}
\hline Temperature $(\mathrm{K})$ & $\mathrm{K}_{\mathrm{c}}$ & $\Delta \mathrm{G}^{0}(\mathrm{~kJ} / \mathrm{mol})$ & $\Delta \mathrm{H}^{0}(\mathrm{~kJ} / \mathrm{mol})$ & $\Delta \mathrm{S}^{0}(\mathrm{~J} / \mathrm{molK})$ \\
\hline 300 & 27436547 & -42.73 & -84.39 & -137.6 \\
310 & 5694377 & -40.07 & & \\
320 & 3623694 & -40.17 & & \\
\hline
\end{tabular}




\section{CONCLUSION}

ALWSD has been used as precursor for the preparation of ALHAC by hydrothermal carbonization, followed by $\mathrm{ZnCl}_{2}$ chemical activation. The effect of operating parameters on the pore characteristics of the carbons produced has been found to be carbonization temperature $>$ carbonization time $>$ impregnation ratio. The activated carbon produced under the optimum conditions (carbonization temperature of $700{ }^{\circ} \mathrm{C}$, carbonization time of $1 \mathrm{~h}$, impregnation ratio of 6:1) attained the $S_{\mathrm{BET}}$ of $1380 \mathrm{~m}^{2} / \mathrm{g}$, a total pore volume of $0.727 \mathrm{~cm}^{3} / \mathrm{g}$ and a pore diameter of $2.27 \mathrm{~nm}$. These results suggest that ALWSD can be used as a low-cost precursor for the production of commercial activated carbon. Equilibrium and kinetic data of DB2B dye adsorption onto ALHAC follow the Langmuir isotherm and the pseudo-second order model. Therefore, ALHAC can be used as a cost-effective adsorbent for environmental and other applications.

\section{REFERENCES}

1 A. Kumar and H. Mohana Jena, Appl. Surf. Sci., 356 , 753

(2015),

https://doi.org/10.1016/j.apsusc.2015.08.074

2 I. Ozdemir, M. Sahin, R. Orhan and M. Erdem,

Fuel Process. Technol., 125, 200 (2014), https://doi.org/10.1016/j.fuproc.2014.04.002

3 D. Angin, Fuel, 115, 804 https://doi.org/10.1016/j.fuel.2013.04.060

M. Napitupulu, D. K. Walanda, Y. Natakusuma, M. Basir and Mahfudz, J. Surf. Sci. Technol., 34, 30 (2018), https://doi.org/10.18311/jsst/2018/11055

5 M. Napitupulu, M. Al-Gifary and D. K. Walanda, Cellulose Chem. Technol., 53, 387 (2019), http://www.cellulosechemtechnol.ro/pdf/CCT34(2019)/p.387-394.pdf

6 J. J. Salazar-Rabago and L. Ramos, J. Environ.

Manage., $\quad \mathbf{1 6 9}, \quad 303 \quad$ (2016), https://doi.org/10.1016/j.jenvman.2015.12.040

7 K. Adouby, L. C. Koffi-Akissi, N. Eboua-Wandan and B. Yao, J. Appl. Sci., 7, 1864 (2007), http://docsdrive.com/pdfs/ansinet/jas/2007/18641872.pdf

8 A. G. S. Prado, A. O. Moura, M. S. Holanda, T. O. Carvalho, R. D. A. Andrade et al., Chem. Eng. J., 160, 249 (2010), https://doi.org/10.1016/j.cej.2010.03.066

9 N. K. Akunwa, M. N. Muhammad and J. C. Akunna, J. Environ. Manage., 146, 517 (2014), https://doi.org/10.1016/j.jenvman.2014.08.014

10 G. H. Oh and C. R. Park, Fuel, 81, 327 (2002), https://doi.org/10.1016/S0016-2361(01)00171-5

11 L. J. Kennedy, J. J. Vijaya and G. Sekaran, Ind. Eng. Chem. Res., 43, 1832 (2004), https://doi.org/10.1021/ie034093f
12 A. H. Basta, V. Fierro and H. El-Saied, Bioresour. Technol., $\quad \mathbf{1 0 0 ,} \quad 3941 \quad$ (2009), https://doi.org/10.1016/j.biortech.2009.02.028

13 H. N. Tran, H. P. Chao and S. J. You, Adsorpt. Sci. Technol., $\quad 36, \quad 95 \quad$ (2017), https://doi.org/10.1177/0263617416684837

14 M. E. Fernandez, B. Ledesma, S. Roman, P. R. Bonelli and A. L. Cukierman, Bioresour. Technol., 183, $221 \quad$ (2015), https://doi.org/10.1016/j.biortech.2015.02.035

15 S. Gaspard, N. Passe-Coutrin, A. Durimel, T. Cesaire and V. Jeanne-Rose, in "Biomass for Sustainable Applications: Pollution Remediation and Energy", edited by S. Gaspard and M. Chaker Ncibi, RSC Green Chemistry Series, RSC Publishing, Cambridge, 2014, Chapter 2, pp. 46-95, www.rsc.org

16 D. C. S. Azevedo, J. C. S. Araujo, M. B. Neto, A. E. B. Torres, E.F. Laguaribe et al., Micropor. Mesopor. Mat., 100, $361 \quad$ (2007), https://doi.org/10.1016/j.micromeso.2006.11.024

17 S. Yorgun, N. Vural and H. Demiral, Micropor. Mesopor. $\quad$ Mat., $\quad 122, \quad 189 \quad$ (2009), https://doi.org/10.1016/j.micromeso.2009.02.032

18 H. Saygili and F. Guzel, J. Clean. Prod., 113, 995 (2016), https://doi.org/10.1016/j.jclepro.2015.12.055

19 J. Yang and K. Qiu, Chem. Eng. J., 167, 148 (2011), https://doi.org/10.1016/j.cej.2010.12.013

20 J. Hayashi, A. Kazehaya, K. Muroyama and A. P. Watkinson, Carbon, 38, 1873 (2000), https://doi.org/10.1016/j.cej.2010.12.013

21 Z. Zhanga, X. Luo, Y. Liu, P. Zhou, G. Ma et al., J. Taiwan. Inst. Chem. Eng., 49, 206 (2015), https://doi.org/10.1016/j.jtice.2014.11.024

${ }^{22}$ K. Mohanty, D. Das and M. N. Biswas, Adsorption, 12, 119 (2006), https://doi.org/10.1007/s10450-0060374-2

23 M. Qingqing, T. Yingmaog, X. Jing, L. Xinping, X. Liren et al., J. Taiwan. Inst. Chem. Eng., 44, 458 (2013), https://doi.org/10.1016/j.jtice.2012.12.006

24 D. R. Zuim, D. Carpine, G. A. R. Distler, A. P. Scheer, L. Lgarashi-Mafra et al., J. Food Eng., 104, 284

https://doi.org/10.1016/j.jfoodeng.2010.12.019

25 A. Gundogdu, C. Duran, H. B. Senturk, M. Soylak, M. Imamoglu et al., J. Anal. Appl. Pyrol., 104, 249 (2013), https://doi.org/10.1016/j.jaap.2013.07.008

26 M. Danish, R. Hashim, M. N. M. Ibrahim and O. Sulaiman, J. Anal. Appl. Pyrol., 104, 418 (2013), https://doi.org/10.1016/j.jaap.2013.06.003

27 I. Langmuir, J. Am. Chem. Soc., 40, 1361 (1918), https://doi.org/10.1021/ja02242a004

${ }^{28}$ H. Freundlich, J. Phys. Chem., 57, 385 (1906), https://doi.org/10.1515/zpch-1907-5723

29 M. Temkin and V. Pyzhev, Acta Physiochim. $\begin{array}{llll}\text { USSR, } & \mathbf{1 2}, & 327 & \text { (1940), }\end{array}$ https://ci.nii.ac.jp/naid/20000744365/

${ }^{30}$ H. N. Tran, S. J. You and H. P. Chao, J. Environ. Manage., $\quad \mathbf{1 8 8}, \quad 322 \quad$ (2017), https://doi.org/10.1016/j.jenvman.2016.12.003 
31 S. Lagergren, Kungliga Svenska Vetenskapsakademiens, 24, 1 (1898)

32 G. Blanchard, M. Maunaye and G. Martin, Water Res., 18, 1501 (1984), https://doi.org/10.1016/00431354(84)90124-6

33 X. Zhou and X. Zhou, Chem. Eng. Commun., 201, 1459 (2014), https://doi.org/10.1080/00986445.2013.818541

${ }^{34}$ K. V. Kumar, K. Porkodi and F. Rocha, J. Hazard. Mater., 150, 158 (2008),

https://doi.org/10.1016/j.jhazmat.2007.09.020 